\title{
nature
}

\section{New ways with official secrets}

\section{The long-awaited proposals for the reform of the British law on official secrecy are better than expected, but leave many details to be hammered out.}

PARANOIA is the natural condition of democratic governments, which are perpetually bemused that those who collectively elected them to office are so consistently unappreciative of their defence of the public interest. This misunderstanding of the elected by their electors is nowhere more prevalent than over government policies on secrecy and nowhere more justifiable than in Britain, whose governments have been saddled since 1911 with an Official Secrets Act that is both draconian and so draconian as to be ineffectual. The act consists of only two sections. One declares espionage a crime, and is not controversial; the second makes it a criminal offence for government officials to disclose "unauthorized" official information and for other people to receive the same. Since long before 1972, when a committee under Lord Franks was set up to recommend reform of the act, it has been generally agreed that the act is too broadly drawn; a more practical objection is that governments have learned by experience that juries will not readily convict people of offences under the disputed section. But successive governments have failed to a find a formula for reform - until now.

The British government's white paper (policy document) on the subject, published last week, is a good first approximation to enlightened reform. First, the categories of information whose disclosure will be a criminal offence are more narrowly defined than even Franks recommended (in 1972). Second, although the intended legislation will apply criminal sanctions to people other than government officials (such as journalists) who disclose information in the protected categories without authority, the penalties will be decided by the courts, before which the government will usually have to prove that disclosure has damaged the public interest and that the discloser had reasonable cause to believe that it would do so. (For government officials accused of telling unauthorized tales, the onus will be on them to prove they could not reasonably have known that harm would be done.) Third, the white paper specifies, for each of the protected categories of information, tests of when harm has been done that appear to have been sensibly and intelligently drawn. That is the good news.

\section{Provisions}

The other side of the coin has two faces, one particular and one general. Many of the details of the proposed bill could turn out to be unduly, even unintentionally, repressive. For example, it is proposed that any disclosure about security and intelligence by a member of the intelligence services should be considered to be harmful; plausible though this may seem, such a stipulation will effectively prevent members of the British intelligence services from making public their organization's involvement in illegal acts. Dr David Owen was right to insist in the House of Commons last week that this provision is acceptable only if there is some means, independent of the government, of monitoring what the intelligence services get up to. It is also proposed that the disclosure of information about British international relations (another protected category) should be considered harmful if it prejudices relations with another government, an interdiction that on the face of things would prevent the publication of news of the British equivalent of the Irangate dealings (if there were one). These and other anomalies are all the worse because the government intends that the public interest should not be an allowable defence against a criminal charge. And how will international publications such as this (Nature is printed at four centres) be affected by the provision that prior publication elsewhere of proscribed information will not be a defence against prosecution? These are matters that will be looked at vigilantly when the bill is published.

\section{Objection}

The more general objection to last week's white paper concerns not the proposed reform of the Official Secrets Act, which will at least let people know where they stand, but the general climate of secrecy in Britain. Constitutionally, this derives from the doctrine of the collective responsibility of ministers, giving them sole titular responsibility for authorizing the disclosure of official information, and their immediate officials the opportunity of making partial (in both senses) leaks of it. While there is no reason why reform of the law on secrets should be accompanied by a more open policy on official information outside the protected categories, that is at least as urgent a need (and would make the forthcoming legislation more palatable).

Just how such a policy should be defined is another matter. The view that Britain needs an analogue of the US Freedom of Information Act is constitutionally inappropriate, but experience over the past decade with the working of the act in the United States has not been particularly encouraging. What is needed, in Britain and elsewhere, is a presumption that the government has a duty to answer legitimate enquiries from responsible sources on matters on which it has already made up its mind - and to do so truthfully. The present nudge and wink system by which the background to government policy is explained is as often damaging to the government as to public understanding. One obvious illustration is the now well-known disagreement between the Prime Minister and the Chancellor of the Exchequer on exchange-rate policy; on such a difficult issue, it would not be surprising that two such powerful people should disagree. But in the absence of more than the sketchiest information about the origins of the dispute, the difference of opinion has been dramatized and also trivialized by being represented as a personality clash pure and simple. Who can benefit from that? On a more practical matter, it would not merely satisfy curiosity but be of some public benefit that the basis of the government's decision to stay as a member of the European high-energy physics laboratory (CERN) at Geneva (provided the cost does not exceed $£ 45$ million a year - see page 4) should be widely understood: is this the research councils' sober judgement of what they can afford (and, if so, what will they do with the $\$ 10$ million a year they will save?), or a political guess at what is practicable? It should not be impossible to devise a published code of conduct that would ensure a flow of legitimately publishable information without embarrassing the British government's legitimate requirement that policy not yet formulated should not be compromised. That (see Nature 333, 101; 1988) is how, in Britain, the government might also arrange that its free press acts responsibly. 